\title{
Oral Ixabepilone
}

National Cancer Institute

\section{Source}

National Cancer Institute. Oral Ixabepilone. NCI Thesaurus. Code C63478.

An enteric-coated formulation of ixabepilone, a semisynthetic analogue of epothilone $B$ and a non-taxane tubulin inhibitor, with antineoplastic activity. Ixabepilone binds to and stabilizes tubulin molecules, thereby interfering with the dynamics of microtubule assembly/disassembly. This results in cell cycle arrest at the G2-M phase and leads to apoptosis within fast growing tumor cells. This agent demonstrates antineoplastic activity against taxane-resistant cell lines. Compared to intravenously administered ixabepilone, the oral formulation provides a more manageable way to administer this agent. 